\title{
The Hero-Leader Matrix in Business and Cinema
}

\author{
Olivier Fournout $^{1}$
}

Received: 6 June 2014 / Accepted: 7 February 2015/Published online: 11 February 2016

(C) The Author(s) 2016. This article is published with open access at Springerlink.com

\begin{abstract}
Textbooks and manuals on management suggest that managers are heroes who deal with difficult problems of collective adaptation and change. American films are similarly built on the premise of a hero confronted with extremely difficult situations. What if this hero figure promoted for so long in both management literature and the American film industry was the same at the structural level? This paper will attempt to clearly define the ethical performance of heroes that is perhaps shared by the imagination industry (hollywood) and the workplace on the long run. We shall follow this picture of a hero-leader in the ethics of business and cinema through a large corpus of movies and writings on management and provide a set of six features for examining both, a common heroic structure we shall call the Hero-Leader Matrix.
\end{abstract}

Keywords Management - Heroism · Leadership · Pattern $\cdot$ Action $\cdot$ Interaction $\cdot$ Innovation

\section{Introduction}

"I'm the king of the world!", the hero of the 1997 film Titanic happily announces from the prow of the huge transatlantic steamer. The model of a hero Hollywood here

I would like to warmly thank Mike Dickman, who, among many other activities, translates South African poetry, and has helped me through the nuances of American language while writting this paper.

Olivier Fournout

olivier.fournout@telecom-paristech.fr

1 Telecom ParisTech, Département SES - Institut Interdisciplinaire de l'Innovation, Unité Mixte de Recherche CNRS, 46 rue Barrault, 75013 Paris, France offers the world is no less than the body of a democratic king-young, open minded, adventurous, clever, surfing towards the Promised Land and in love.

Can managers be compared to kings, though?

Well, yes, they can.

In a 40-page chapter of The age of Heretics, A history of the Radical Thinkers who Reinvented Corporate Management, 1996, called 'Parzival's dilemma', Kleiner compares the modern manager to the knight of the Round Table Parzival who becomes the Grail King, but who first has to find the courage within himself to ask the wounded keeper of the Grail "What afflicts thee, uncle?" just as a manager or an Organization Development consultant helps heal organizations by finding the courage to follow his own intuitions and ask unsettling questions about the current state of affairs (Kleiner 1996, pp. 186-225).

In this paper, I will focus on a question initially raised by sociologists of the cinema considering the relationship between societies that produce films and the societies created in films (Kracauer 1947; Jarvie 1970) and will apply it to examining the relationship between management and American movies, that is to say between one of the fundamental ethics governing modern economics and one of the most popular manifestations of the imagination industry, Hollywood.

This paper has six sections. First is an overview of what ethics might mean when it comes to comparing organizational behaviour and representations in popular culture. Second is a review of the literature exploring the links between management and cinema. In the third section, I will justify the hypothesis of a long-term pattern of action shared by the movie industry and managerial culture. The fourth section will present research scope and methodology as applied to a long-term corpus of writings on management and films of fiction. Then, getting to the core of 
content analysis, I shall describe the profile of a HeroLeader in business and cinema and provide a set of six features for examining it, a heroic structure I shall call the Hero-Leader Matrix that spells out the nuts and bolts of the Hero-Leader's communicative power. In the final section, I shall discuss these results, noting certain difficulties and calling for further investigation in two directions.

\section{Ethics and Aesthetics of Human Relations}

In this paper, I will show that managerial thought and cinema reinforce each other in that they converge on a single set of ethical requirements that combines the power of mass media with the "spirit of capitalism" (Weber 1904).

What does a set of ethical requirements encompass? Ethics will be considered in a broad sense here. An ethical requirement tackles the problem of what may be considered good (or bad) as regards many different aspects of life. It may be related to a practical knowledge or science that Locke, for example, called "practica", that is "the skill of right applying our own powers and actions, for the attainment of things good and useful. The most considerable under this head is ethics (...) The end of this is not bare speculation and the knowledge of truth; but right, and a conduct suitable to it" (Locke 1689, p. 442). For William James, the father of modern pragmatism, it is clear that such considerations concerning good life have an impact on what we think is true. As long as an idea is helpful in life's practical struggles, it can be accepted as a truth: "The true is the name of whatever proves itself to be good in a way of belief" (James 1906, p. 30). When Weber (1904) tries to understand the roots of capitalism, he takes very seriously the ethical recommendations of the Protestant ascetic movement, defining what he calls a "spirit", an "ethos", forming what is "most characteristic of the social ethic of capitalistic culture" and "in a sense the fundamental basis of it" (Weber 1904, p. 19). This methodological gesture, no longer as regards a religious corpus but concerning the managerial literature from the 1960s to the 1990s, is explicitly replicated by Boltanski and Chiappello (2005) with the same hypothesis that it forges an "ethos", a practical spirit essential to the organization of the workplace in our modern economies: in Weber's words, an "immense cosmos in which the individual is born" (Weber 1904, p. 19).

One thing I must obviously add to Weber, Boltanski and Chiapello's approach of modern ethics at work is taking seriously the popular moving picture culture as relevant to the forging of an "ethos". It may be objected that fictional works speak only to our imagination in a sort of disconnection with reality, but that is forgetting that "imagination is the chief instrument of the good" and thus "art is more moral than moralities" (Dewey 1934, p. 362). Movies can be taken as real images of a possible embodiment of ethical practices. They put into flesh (that of the actor, but still, a real sensitive body) models of actions and interactions that otherwise, dressed in words in literary works, may seem more abstract or mere wishful thinking. That is why John Dewey develops this interesting argument of a "distinctive aesthetic quality in moral action" and that "one great defect in what passes as morality is its anaesthetic quality" (Dewey, p. 40). The idea is not that watching a film makes us mechanically better, but that, both in life and in the moving pictures, action without a body cannot be achieved; it has to be seen, which thus gives it an aesthetic quality. In Cold Intimacies, The making of Emotional Capitalism, Eva Illouz studying the influence of psychoanalysis recognizes that "it could spread widely in all venues for American culture, most conspicuously in the movies and in advice literature" (Illouz 2007, p. 9). Movies and practical literature applied to self-help and managerial skills together contribute to the shaping of a new ethics. Later in the book, she notes that "Numerous guidebooks to success in the corporation read like manuals in semiotics with chapter heading such as "Signs and Signals", "How to Identify Cues and Clues", or "The Meanings behind the Words"” (Illouz, p. 20). Because ethics express itself through signs and signals and the aesthetics of the cinema is skillful in staging such signs and signals, it seems interesting to take the evaluation of what they may have in common as a field of research.

In the present paper, I will read manuals of management and films as the media through which ethical requirements in the workplace in a broad sense, or, in other words, dispositions toward action and interaction aiming at things good and useful within organizations, take form-a visible, audible and readable form. As will appear later, these ethical requirements cover great existential postures, with dynamic tensions between them, through which ethics and aesthetics of human relations are intertwined.

\section{Management and Cinema}

Films are often used to illustrate management concepts. They are considered "excellent teaching tools (...) for an examination of business ethics" (Shaw 2004, p. 167). Well-chosen extracts serve as great examples of how human beings relate to each other. For example, the book Using films to visualize principles and practices displays a table of contents typical of any management textbook. Each chapter digs into a particular issue- "motivation", "team management", "conflict"...-and examines scenes chosen from over a hundred movies (Champoux 2001). 
Constructing leadership, Reflections on film heroes as leaders starts with an unambiguous assessment: "Films are like motorways into people's heads" (Rombach and Solli 2006, p. 9). In Passion and Discipline, a documentary film, James March considers the figure of Don Quixote, exemplified in the original novel and in various adaptations to the movies, as a paradigm of modern leadership (March 2003). In management, as in other aspects of life, spectators are likely to develop a "referential reading" of cinematographic fictions (Liebes and Katz 1990) whereby they link the fictional elements on the screen with their own real-life experience: "Viewers relate to characters as real people and in turn relate these real people to their own real worlds" (Liebes and Katz 1990, p. 100).

Many articles minutely compare the working world and the image of it in cinema profession-by-profession and sector-by-sector.

Professional categories are studied through their cinematographic representation: business executives (Feldman 1992; Johnson 1995; Soter 1996), non-profit CEOs (Lee 2004), doctors (Paietta and Kauppila 1999), public relations practitioners and officers (Miller 1999; Lee 2001; Ames 2009), accountants (Beard 1994; Dimnik and Felton 2006; Felton et al. 2008), construction engineers and lawyers (Langford and Robson 2003), workers (Ross 2001), and trade unions and management gurus (Hassard and Holliday 1998).

Several studies examine the production systems, work sites and social problems in companies shown in cinema: universities and campus classrooms (Hinton 1994), burlesque treatment of assembly-line work (Guigueno 1998), the reaction to AIDS in the professional world (Hassard and Holliday 1998), the subjective dimension of relationship to work (Jeantet and Savignac 2012), capitalism and its links with themes such as poverty, health and the insertion of immigrants, this last question being all the more crucial in that many of the first Hollywood films were made by groups of immigrants (Lithgow et al. 2001).

Within recent years, some research has been devoted to exploring links between popular movies and managerial theory and practice on a large scale. Bell (2008) and Lamendour (2012), both working on a large film corpus (100 films, predominantly American for the first, 300 films, predominantly French, for the second, both classic and contemporary), come up with a general view of the great long-term changes in the way management is presented in film. For Bell, it is clear that managerial issues change over time and that 1950s managers are not the same as managers of the 2000s. Still, themes may emerge at a certain time and have a very long life ahead of them, such as, for example, the rise of the rational manager or struggle for upward mobility. As Bell admits, images of the organization man during the 1950s "helped to establish some highly influential concepts that continue to inform the way we continue to think about work and the workplace today" (Bell 2008, p. 89). For Lamendour, there are three distinct periods. In the first of these (1895-1913), the relationship between capital and work is taken as an ensemble, and management is considered as essentially relational. In the second phase (1914-1947), the manager is recognized as a central figure in the company and is characterized by optimism, inventiveness and heroism. Finally, in the third of these phases (1948-2005), an era of suspicion, criticism and disenchantment arises.

It has been emphasized (Soter 1996) that cinema presents an image of Corporate Do-Gooders invested in the creation of values and employment, with a paternalistic discourse in favour of the empowerment of employees, but equally, or perhaps even more frequently, of the Big Bad Boss. Bell insists on "the predominance of negative portrayals of organizations in film" (Bell 2008, pp. 8-9), a critique of the excesses of capitalism, uncontrolled competition, egocentricity, the dehumanization of systems and so forth. A film like The insider, 1999, that questions morality under the pressure of multinationals and media logic offers researchers an opportunity to use models of practical ethics as a film analysis framework (van Es 2003).

Gangster films are certainly not models to follow as concerns business but are rich in lessons as regards decision processes, collective, or individual. The godfather (1972) prompts thought on Don Vito's reflective manner and his rational and irrational, conscious or unconscious patterns (Rombach and Solli 2006, pp. 158-164). Even though the film does not exactly reflect reality, it provides an occasion to introduce concepts or norms that come closer to it. If, for example, Michael Corleone seems to take on the role of chief in a remarkably painless way, professors of management and administration remind us that empirical data show that new managers' romantic image of leadership soon takes a tumble and that the transition "from being popular to being respected" and "from defending [one's] own position to defending an entire organization" is not easy (Rombach and Solli 2006, pp. 165-167).

\section{Toward a Heroic Pattern of Action}

From the studies mentioned in the preceding section appears a convincing argument for the possibility of example being drawn from cinema scenes and characters to evoke one or other aspect of professional ethics, examples that manifest their pertinence within the framework of a profession, a business sector, a social or political problem or a period in history. The objective is to create a correspondence between such-and-such a fictional situation and 
a given moment in time, context, or concept of organizational life. Different types of action by various kinds of heroes in film scenes of various sorts serve as particularly rich supports for the transmission of different methods and practices of management, leadership, negotiation and/or communication.

This general overview of the literature revealing links between cinema and management gives a sense of the diversity of films that can bring about fruitful analysis of a given domain of business ethics. Various sectors would choose different films in support of the same general claim: that there is a correspondence worthy of study between film and managerial issues.

The question then arises: would any film do?

From a strictly logical standpoint, there is one research hypothesis not covered by current literature: what if, in the long run and at a structural level, there was a type of hero or pattern of action in harmony with the time shared by cinema and managerial ethics? We might then be able to appreciate how virtually any film, not just those that "contain scenes set in conventional work organization such as offices, factories and shops" (Bell 2008, p. 8), might serve the purpose of illustrating managerial concepts through film.

My working hypothesis is that cinema heroes and efficient managers as described in the manuals of management actually share a certain number of behavioural traits. According to this hypothesis, such traits converge in the type of posture assumed by hero-leaders in action and interaction with others-a posture at the same time mental and practical. Otherwise put heroes in films and the leaders described in managerial literature work a psycho-sociopragmatic synthesis that stabilizes a manner of acting and interacting in the world.

The approach is complementary to that of "story telling" applied to the exercise of leadership (Denning 2005). It differs from the study of the major phases of storytelling and the narration of myths (Propp 1928; Campbell 1949) in that the centre of attention is the model of the hero who enacts them rather than the stages of the action of the tale. The analysis includes the attitude of the hero in the flow of events but does not enter into the details of the succession of movements commonly referred to as 'the story', the sequence of trials experienced by the hero and so perfectly described by Campbell (1949).

The cinema thus does more than just illustrate the concepts of management. It coproduces a unique heroic profile I call the Hero-Leader in Business and Cinema whose robustness stems from the fact that it is forged from the coming together of prevailing fictions (Hollywood, American cinema, TV series) and the managerial literature that expounds the precepts of work organization. The power of cinematographic fiction and the recommendations of management thus both spring from a common heroic structure shared, in the long run, by a large number of films and the central ethic of contemporary economics.

The ultimate aim is not to prove that American film impacted American management practices or, on the other hand, that American film makers made films about their impression of American business people and how they acted. Firstly, it may well work both ways: that cinema and management impact on each other by way of many different mediations and influences. Secondly, they may simply both be part of a more general, diffused set of ethics, spirit and behaviour patterns which would then call for the opening up of a new series of research questions.

\section{Research Scope and Method}

In this article, I seek to show that the hypothesis of a common heroic structure in treatises concerning the organization of the workplace and popular film is borne out in many cases and over a long period of time. The heroic structure I intend to reveal is based on the inductive analysis of a two-dimensional corpus (works on management and films). I explore how the main elements for description of this corpus can work together and become creators of meaning by crossing the frontiers of fiction and reality.

\section{Time-Period: A Long-Term Corpus}

For both the management literature and the movies, the scope of the study covers a large period of time: from the 1930 s up to the present. Starting with the 1930s has an advantage. That was when the first non-silent movies appeared and great and popular films assumed the form we know today. Furthermore, it was at this same time that the theme of human relations entered the field of studies concerning the organization of the workplace, especially in the work of Elton Mayo as expressed in his The human problems of an industrial civilization (1933).

\section{Sources: A Transmedia Corpus}

For management, I kept to a corpus of fifty-odd textbooks, manuals and papers on management and human relations as applied to leadership, negotiation and interpersonal communication in organizations, a choice made within the vast body of classics on management and company life. My method of choice did not entail skimming through a profusion of references to simply keep those that suited my system. Instead, one after the other, I included in my study whatever seemed recommended in the management field, widely published, quoted or reedited. I obviously don't claim to have examined all the most important texts on 
management, but the references I use represent a part of them. They are the ones used by management trainers, teachers, specialist researchers, consultants and actual operational managers. Many of them appeared in prestigious university editions (Harvard, University of Chicago Press, etc.), were signed by university professors (Stanford, MIT, Harvard, Brandeis etc.) or consultants of reputed firms (McKinsey, The Gallup Organization, etc.), reedited and translated into several languages, based upon vast empirical studies carried out in the managerial milieu. Not uncommonly the authors are researchers, and this led me to add a few articles to the bibliography to complement the books whose distribution is wider.

For a complete list of the works in the corpus, the reader is referred to the Management Bibliography in the appendices. There he will find a few books written by people active in the business world as such, one a well-known business executive in the energy and technology sectors (Welch), the other a successful entrepreneur (Trump), both of them "New York Times bestsellers". There are also a few manuals of advice on relationships such as those by Carnegie, historical reference-point in the communication and leadership in companies, and the liberal professions training market, now an international "brand" found in upward of seventy countries.

References are quasi-exclusively American for the simple reason that they dominate management studies and are translated, quoted, adopted and recognized throughout the world. This does not mean that I contend that influence is entirely one-way, from the US to the rest of the world. As evidence of a movement in the opposite direction, I include a work on Kurt Lewin and the influence of this researcher of German origin on Training Group practices since the 1950s, and two books highlighting the spread of the Toyota method in the United States. I also include two works by French researchers, one by Michel Crozier who worked in the States over a long period of time, and the other by Luc Boltanski and Eve Chiapello who studied a large corpus of management texts representing what they call "the new spirit of capitalism" (1999).

Because of the importance of negotiation situations in the management profession and in films, over and above the testimony of an industrial relations and labour relations pioneer (French), I also include two classics on negotiation methods from Harvard (Fisher, Ury) as well as a reference on the negotiation dimension of management (Lax, Sebenius) and a more recent work by Lempereur and Colson (a transatlantic work in that Lempereur is a professor at the Heller School for Social Policy and Management and Colson the director of the Institute for Research and Education on Negotiation in Europe).

As regards cinema, my corpus covers more than two hundred films, nearly all of them American (USA). They belong to very different genres (action, western, police stories, drama, etc.) and exclude only comedies which obey very different codes. ${ }^{1}$ I chose them by letting myself be guided by both my early contact with cinema and by the DVD or VOD market through which re-editions are available. There are blockbusters in it, but that is not the only criterion. As with the texts on management, it is not that I watched the films and then kept those I considered most representative of my hypothesis. Instead, I watched them one after the other, processing each of the films individually yet noting that they all presented a sort of unity. This was already an interesting research result, the fact that there seemed to be a fairly stable "pattern", "structure" or "design".

As for the difference in figures-50 textbooks versus 200 films - and why one management textbook should have the weight of four Clint Eastwood films, there are two answers. One for the spectator of popular culture. It seems fair enough that watching The good, the bad and the ugly is not as demanding as reading The Functions of the executive, so, on the grounds of "cognitive effort", one to four is not excessive. The other answer is for researchers in the human sciences. My feeling as I progressed through my dual corpus is that "books on management" refers to a unified non-fiction genre: the books look alike and a sense of the saturation of the corpus arises rather quickly. Despite the various schools of thought, the "family" is clear. Films, on the other hand, belong to very different genres: Westerns, SF, police stories, adventure, politics and so on. It is easier with films than with managerial texts to lose track of the unity of the hero figures, their collective flesh. So it was important for me to verify that the hero-leader matrix was operational in films as different as, say, Lawrence of Arabia, Planet of the Apes, Dr. Jeckyll and Mr. Hyde and The Godfather... So, with the matrix in mind, I did indeed watch more films than I read books (at least, in terms of numbers, but, again, not in terms of the effort dedicated to the task). At one point, one to four appeared a good balance.

\section{Analytical Method: Readings and Annotations: The Writer as Subject}

Content analysis was carried out through a parallel reading of textbooks and films. ${ }^{2}$ As a method, I concentrated on the congruence between the profiles of film heroes and 'efficient' managers as presented in the manuals. Had I, on the other hand, focused on differences, I would, of course, have found that they are not exactly the same.

\footnotetext{
${ }^{1}$ Comedies are covered in Cavell (1981).

${ }^{2}$ I fully agree with Cavell (1981), who calls his accounts of films "readings" of them.
} 
The first stage was as inductive as possible, mainly through trial and error, partially feeling my way in a profusion of directions. The main features then slowly began to stabilize into families and groups, and thus, after many attempts, I settled on six thematic fields defined by a relative internal heterogeneity. That is to say that each field is a collection of semantically similar yet different notions. Then, to explain each one, I decided on a term to qualify them, thus giving birth to six 'labels' or acronyms which I describe in the HeroLeader Matrix (cf. next section). They are reductive, mere indications of a field to which, in every case, one then has to restore its actual riches. For example, with the term Hero Negotiator indicated by the acronym [NEG], one is to understand a negotiating activity in the strictest sense (bargaining), but also a tendency to dialogue, discussion and compromise, a chance for words to resolve conflict, a privileging of the confrontation of points of view in order to solve a problem, to build an agreement, etc. The acronym [NEG] is an index opening toward a range of complementary terms.

I also had to be fairly supple in my interpretation of certain signs arising from the two dimensions of the corpus. For example, the effects of the power and omnipotence signified by the acronym [SPW] for "Superpowered" are not always expressed in the same way in cinema and business. The pistols of westerns, gangster films and cop movies do have their equivalents in management, albeit of a different nature in that combat generally manifests there as the struggle for recognition, verbal intimidation, assumption of power, personal assertiveness and so on.

Once these analytical notions were clear, I applied them more directly to new films and texts, carrying out my content analysis "by hand" via hand-written notes.

Given the size of the corpus, and the time I am spending on it (in the evening for the films), I have wondered about the possibility of automation but consider that, at my present level of semantics, research via text and image analysis software would not be possible. Whatever the case, I do not use them and so continue to take copious notes as I read films or texts.

On this particular point, as well as on others such as the stabilization of the features of the hero-leader, my position as analyst can be questioned. I do not believe such analytical research can be conducted without the involvement of the researcher's subjectivity, so the question arises: what sort of subjectivity? In this I feel very close to the approach of subjectivity as proposed in the theories of phenomenologists such as Marion (1997). In this approach, it seems not only possible, but even obligatory, to articulate a demand of careful description of what is given by a phenomenon itself (be this an object, an event, a discourse, a piece of art, an ethos, an idea...), and, by way of corollary, to allow the subjectivity of the observer, including sensation and intuition and not just abstract intelligence or quantitative proof, to function fully. Objectivity and subjectivity thus come to a common ground.

In my own work, this meant that I spent a long time seizing what books on management and films were presenting in terms of theme, image and practical conduct. In order to do so, however, I did not rely merely on what was immediately countable as a material identity. I did not, for example, count occurrences of the word "death" in the manuals nor appearances of gun shots in films. Yet, at a certain point, as an observer both objective and subjective, I made a synthesis around the notions of super-powers, violence and struggles in both films and in the organizational world. Thus, the main features of the hero-leader result from an accurate description where the small details rejoin the larger picture and inductive reasoning comes to a general statement, closer to existential issues than to purely materialistic accounts of reality. Jean-Luc Marion applies his method in a convincing manner to phenomena such as historical events and human sensation as well as to cubist pictures, and, in my experience, it works out well for moving pictures and managerial thought.

The fact that subjectivity is part in the process implies that other readings of the same corpus, are, of course, welcome. It is true that other terms with different connotations may prove stimulating to qualify the features ('identity' instead of 'interiority'; 'cooperation' rather than 'negotiation'). The choice of words is mine, and when I had a hesitation, I preferred larger categories (such as "on a mission") capable of working in both the mythological world of fiction and the pragmatic world of action. Of course, other features of the hero-leader could be pertinent. I do not pretend I collected them all, but I do think the ones I have pointed out are emblematic and structural in accordance with what is truly given by the corpus.

\section{Results: The Modern Hero in Business and Cinema}

My presentation of the results is structured around four points. I shall first make two observations on the notion of heroism as applied to my corpus. I will then suggest a set of six features for examining the positions of leaders as presented in management literature and heroes as they appear in films, a structure I call the Hero-Leader Matrix. Thirdly, I will consider the six facets of the Hero-Leader Matrix as expressed in the managerial field in more detail. And, finally, I will show how the Hero-Leader Matrix functions in a handful of movies.

For reasons of space, I will obviously not be able to cite all the management manuals or films I have analysed but will keep myself to a few representative quotations from the former and case studies for the latter. 


\section{The Figure of the Hero}

\section{Why Heroes? Leadership as Heroism}

Why describe managers or leaders as heroes? Where does this idea come from? The basic answer is that manuals on leadership clearly suggest that managers are a species of hero faced with difficult problems of collective adaptation and change. In like manner, American films are built on the premise of a hero confronted with highly complex or charged situations. This is their primary common ground.

On the management side, let me quote some texts in which leadership is described as a matter of heroism: Buckingham asks managers to "create Heroes in Every Role" (1999, p. 200). Heifetz, in Leadership without easy answers, writes "If we want to generate more leadership in our society, we have two options. We can embolden a greater number of people toward heroic effort, and we can investigate ways to lead that reduce the likelihood of personal injury, even to the hero, so that more people can step into the fray" (Heifetz 1994, p. 235). In a book called Managerial Psychology published in 1958, Leavitt recognizes that the actions of businessmen resemble those of Hollywood (1958, p. 244). Crozier also speaks of heroes who bring innovation to companies (1989, pp. 45, 215).

Rereading Parzival, Kleiner (1996, pp. 186-225) finds in the Grail quest hero the properties of a contemporary manager. Parzival is a German novel of the Middle Ages and was widely known in manuscript form before being printed. Written around 1200-1210 by Wolfram von Eschenbach, it was inspired by Chrétien de Troyes (Perceval, approximately 1180) and presented a new version of the Grail Story. Kleiner places the accent on the dilemma the knight faces at a crucial point in his life, a dilemma of note in that it is the choice Parzival makes that then condemns him to the long and circuitous journey that constitutes the heart of the tale.

At this key moment of the knightly tale, Parzival is introduced into the court of King Anfortas, guardian of the Grail. The king is wounded. During the banquet, Parzival wants to rise and ask the king a question but keeps his silence. The dilemma is as follows: either he must follow his impulse, stand and speak, or respect the rules of chivalry, the rules of precedence and good manners, and hold his tongue. By keeping silent, Parzival misses the opportunity to heal the king and is thus fated to 5 years of wandering, after which he returns to the king's court and asks him the delivering question: "What afflicts thee, uncle?" Anfortas is saved and Parzival is proclaimed Grail King.

Like the thinkers and practitioners of management says Kleiner, the Grail hero is someone who strongly feels the need to question and who steps aside from convention in daring to ask. He stands up and takes the risk of affirming himself against strict obedience to rules. The dilemma and the heroism both stem from the fact that there is no readymade solution. Parzival's modernity is born with this capacity to find in himself the strength to break with habit or culture, and, at great risk and peril to himself, bring change in the hopes of a reward worthy of the risks entailed.

\section{Why Not Only Hero CEOs? Managers as Everyday, Ordinary Heroes}

When speaking of heroes in management, should one speak only of "hero CEOs"? It is true that, just like Hollywood heroes, the stature of emblematic leaders like Steve Jobs, Bill Gates or Jack Welch is larger than life in the public imagination. The book Greatest business stories of all time calls itself "a book of heroes" (Gross 1996, p. 1). But heroism in the workplace is not that limited. Most management manuals are interested in a form of leadership that is much wider. Mayo calls for a "new administrator": "The world over we are in need of an administrative élite who can assess and handle the concrete difficulties of human collaboration" (Mayo 1933, p. 185). This call to elitism is found throughout the hierarchical chain. Anyone even temporarily assuming formal or informal authority, expertise or influence is likely to be put to the test of some kind of heroism. In successful companies, there are "armies of dedicated champions" who are asked "to shine", "satisfying the individual's need to be part of something great" (Peters and Waterman 1982, pp. xxiixxiii). The purpose is "to achieve extraordinary results through ordinary people", through a metamorphosis by which "the average Joe and the average Jane" are turned into "winners" (Peters and Waterman 1982, p. 239). In Xteams: how to build teams that lead, innovate, and succeed, it says: "This book is the story of X-Teams. It is a story about ordinary people doing extraordinary things" (Ancona and Bresman 2007, p. 9). Badaracco speaks of "patient, unglamorous, everyday efforts" (Badaracco 2002, p. 9). Elsewhere he examines specific defining moments managers face and notes that "these situations are moments of potential greatness" (Badaracco 1997, p. 120). Buckingham praises leaders showing "cool heroism" (1999, p. 73). The kind of behaviour most of the practical literature is interested in is the everyday heroism, a sort of common behaviour which nevertheless nurtures great expectations and faces high tension. Even Jack Welch taken as a possible heroic figure, when he writes a book on his experience, tries to communicate to others his view on leadership as a general recipe for the life of organizations.

Within the limits of this paper, we will not emphasize the differences between CEOs, leaders, managers and project 
carriers... Anyone in charge of others, even a small team, is bound to meet managerial and leadership issues where the questions of self-engagement, influencing others and being influenced by them, are all at stake. Over and above Mintzberg's provocative assessment "let's stop the dysfunctional separation of leadership from management" (Mintzberg 2004), we could at least admit the possibility that, at a certain level of existential commitment and structural requirement, the distinctions that may exist fade away. The patterns of action and interaction, both of an experienced boss and a young professional taking on a first assignment, become comparable and the skills involved in terms of the ethics and aesthetics of human relations similar.

As for the superpowers of many American film heroes, these present only one side of the character. The portrait requires filling out with far more common habits. For example, it may be thrilling to follow the risk-filled life of a secret commando in Spielberg's film Munich yet, apart from the violent scenes, the film shows a team leader who finally seems more like a casual project manager than a soldier on an assignment: he has wide autonomy of action, has to maintain written proofs of his expenses, confronts his hierarchy on the means of his mission, negotiates pieces of information directly with other international organizations, cooks a meal for the team, etc. It is really far more like project management as explained in the most widespread textbooks on the subject. Here again, as with the manuals on company life, we are dealing with a heroic figure who is, to a certain extent, ordinary, and to whom any "normal citizen" or "professional" can relate.

\section{The Hero-Leader Matrix}

I now come to the six main features of what I call the HeroLeader Matrix (see Fig. 1).

My contention is that the major figures in leadership as described in management literature and the profiles of heroes in American movies are the same on a structural level. I shall argue that their final heroic touch consists in a double challenge:

- the simultaneous intensification of all six facets of the Hero-Leader Matrix,

- and the manifestation of a possible synthesis, "collage" or embodiment of these intensified and partly contradictory facets.

In other words, the hero is the one-in business or cinema-who captures maximum public interest by reaching the highest possible point of tension in the HeroLeader Matrix (or by engulfing the Hero-Leader Matrix in the greatest possible tension). What we have here is a kind of performative or dramatic hero. Heroes according to the Hero-Leader Matrix do not have to be moral heroes. Of course, they can, and it is great when they do, but they do not have to, at least according to the Matrix. Film heroes and managers are not always, nor only, positive (for example, in the managerial field, Badaracco 1997, has a whole chapter on the "dirty hands" issues related to management). Whatever their moral beliefs and personal values, Hero-Leaders are more like a dramatic will, a tragic conscience, a soul and body in action, and a performer facing a dangerous world.

The six features giving meaning to the figure of the Hero-Leader in Business and Cinema are as follows:

\section{The Hero-Leader Takes on Roles [ROL] and Displays a Profound Interiority [INT]}

The Hero-Leader assumes roles [ROL], especially social roles (Goffman 1959), and takes on different identities (private or public according to the situation and people with whom he or she interacts). Heroes in both the managerial field and Hollywood movies step into new functions or social environments in which they are forced to learn new customs and habits. The Hero-Leaders know how to play with signs, costume, style and voice, both to enhance their own self-assertiveness and to promote ideas, projects and values. Heroes often play at being someone different from who they really are. They disguise themselves. They may wear masks. They make the show.

At the same time, the Hero-Leader displays a profound interiority [INT]. He has depth-deep emotions and sensations-and reveals how strongly he or she relates to them. Heroes both in the managerial field and Hollywood movies feel deeply and are in full contact with their environment and the people around them. Constantly listening, they shape what they hear through their own interiority and build their actions on the basis of their inner voice. Through many signs and signals, they exaggerate how strongly they are connected to their sensations, thoughts and emotions. Hero-Leaders have to assume the roles in society into which they are thrown somewhat like an actor taking on a new part. Just like actors following the acting style popularized by the Actors Studio (Strasberg 1988), they listen to their thoughts, emotions and sensations, and as heroes they do it in a very visible manner. Heroes must show how deeply they have dug into their interiority to build their roles (Fournout 2012).

The Hero-Leader is on a Mission [MIS] and is Creative, Unorthodox, Divergent [DIV]

The Hero-Leader is on a mission [MIS]. Heroes both in the managerial field and Hollywood movies work within a framework. They conform to the aims of the task and abide by some type of law, rule or objective, positive, negative or 
Fig. 1 The hero-leader matrix

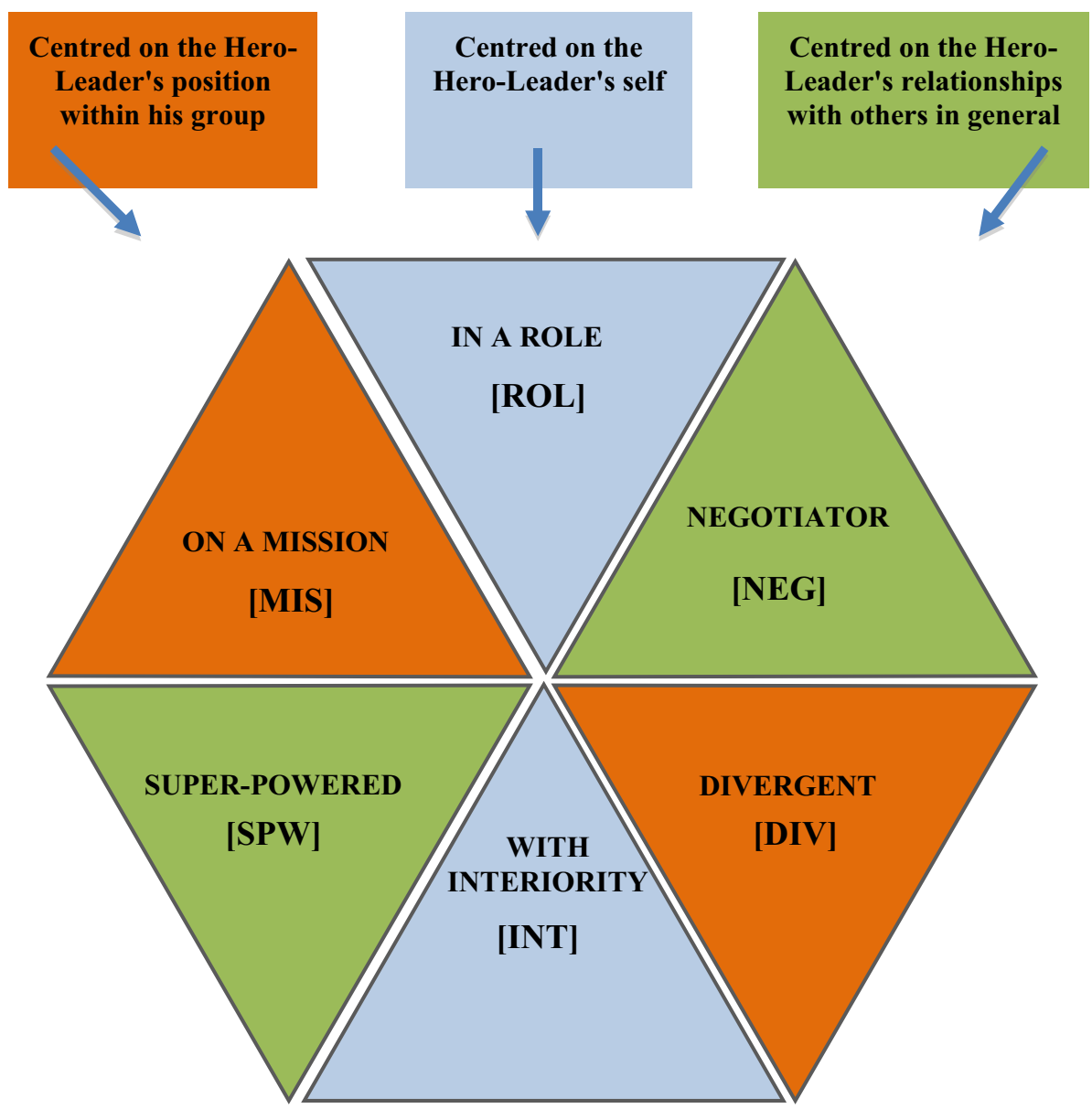

transcendent. This may be a Code of Ethics and Standards of Professional Conduct or an implicit way of life, but the hero always adopts some sort of normative behaviour, aiming at some practical results.

At the same time, the Hero-Leader carries out his or her mission by making creative and unorthodox moves, by being divergent [DIV]. Heroes fall off the edge, step away from the framework. They take unexpected paths and move beyond the scope of normal courses of action. They work within and, at the same time, are outside the framework. They walk apart. They bring change and, with it, relative chaos and improvisation. They are innovative.

\section{The Hero-Leader is a Negotiator [NEG] and Shows Some} Sort of Super-Power [SPW]

The Hero-Leader is a negotiator [NEG]. He gives dialogue a chance. He creates the conditions for a peaceful confrontation of differences. He enhances human cooperation. He facilitates interaction and opens the door to win/win games, compromise and shared leadership.

At the same time, the Hero-Leader is super-powered [SPW]. He or she acts in sudden bursts of all-powerful authority. He has a sense of omnipotence. Heroes in both the managerial field and in Hollywood movies need to show special strength. Despite the risks for themselves and for others, they have confidence in a certain form of violence. They impose their views in a win/lose game. Often their very lives are at stake with the corollary that the people around them are risking their lives too.

\section{The Hero-Leader Matrix as a Whole}

The six facets of the Hero-Leader Matrix function as a whole, each equal to the other. There is no notion of hierarchy or of steps and stages. Nevertheless, the features are paired in tension: assuming an external role as opposed to withdrawing into oneself [ROL/INT], respect for the mission versus the command to step beyond existent boundaries [MIS/DIV] and the call for negotiation in opposition to manifestations of super-power [NEG/SPW]. In this article, I shall start with the two elements more or less centred on the Hero-Leader's self [ROL/INT] then continue on to those having to do with the horizon of the task to be accomplished within a group and thus centred more on the position of the Hero-Leader within the group he belongs to [MIS/DIV] and conclude with the two opening on the type of relationship the Hero-Leader has 
with others in general $[\mathrm{NEG} / \mathrm{SPW}]$. The movement is centrifugal, from the person to the intermediary group, and from the intermediary group to society in general. I insist, however, that I might have chosen another sequence, for example, the negotiations and power structures of human relations might have been invoked first and they do, by rights, belong in the structure I have exposed and at the same level as the other pairs of features. Finally, and in all cases, the big question the Hero-Leader has to face is how to intensify each of the criteria of the Hero-Leader Matrix and to bring them together as a whole (Fig. 1).

\section{The Hero-Leader Matrix in the Managerial Field}

Let me now give an overview of how each criterion expresses itself in managerial literature.

\section{The Hero-Leader Takes on Roles [ROL] and Displays a Profound Interiority [INT]}

Hero-Leaders are great actors playing roles [ROL] and, at the same time, show how authentic and interiorized theirs feelings are [INT].

[ROL] Carnegie (1936) recommends smiling to improve one's communication. Like a movie director working on outer signs, he insists: "You don't feel like smiling? Then what? (...). First, force yourself to smile" (Carnegie 1936, p. 75). For managers, it is a question of multiple role play, widely recognized in the literature: "The managerial role is not a single, invariant one, but a complex of different roles" (McGregor 1960, p. 35); "When the stakes are high, people play the games of organizational life to win" (Badaracco 1997, p. 98). Badaracco's counsel to leaders is "Sometimes play the lion, more often, the fox" (1997, p. 115, with an explicit reference to Machiavelli). Heifetz warns "A person who leads must interpret people's responses to his actions as responses to the role he plays" (1994, p. 263). Leaders are like Hollywood stars: "The charisma derives not only from the person's skills, personality, and devotion but also from the community's investment. As in Hollywood, the star steps into a role that the audience has made" (Heifetz 1994, p. 247). Buckingham therefore advises leaders to "study [their] best in the role" (1999, p. 105).

[INT] Mayo (1933) was convinced that workers in the industrial world are not only performers of a repetitive process but also human beings with a psychology and a personal sense of being, people affected by intellectual and emotional stimulus (1933, pp. 30-37). Changes are always to be studied as changes in mental attitude (p. 57). He thus called for a new administrative élite sensitive to the "human complication of the mechanical and economic" ( $p$. 176 , and the chapter "The problem of the administrator", pp. 168-188), opening up a new era of studies focusing on "psychology in industry" (Maier 1946). Carnegie, although demanding the smile as pointed out in the preceding paragraph, still expected a sincere and genuine smile, "a real smile" (Carnegie 1936, p. 72). "Here is the way the psychologist and philosopher William James puts it: 'Action seems to follow feeling, but really action and feeling go together" (p. 75). When studying executive responsibility, Chester Barnard notes "It is a matter of right or wrong in a moral sense, of deep feeling, of innate conviction, not arguable; emotional, not intellectual, in character" (1938, p. 266). According to McGregor, man works not only because he is forced to but also because he likes to "exercise self-direction and self-control in the service of objectives to which he is committed" (1960, p. 65). For Kleiner, change in organizations requires "going on an internal Grail quest of your own", "continually building the capacity in yourself to stop the action and say to yourself: 'What is keeping me from asking what afflicts the King?"” (1996, p. 216) and "becoming hyperaware of your own impulses and thoughts" (p. 219). If it has always been evident that "leadership arouses passion" (Heifetz 1994, p. 13), the importance of feelings and affects in action has been generalized through the label "emotional intelligence" (Goleman et al. 2002). Heifetz, with many others before and after him, asks for a careful introspection on the part of leaders. He demands of those who lead to "listen, using oneself as data", that is, to become conscious of one's "own ways of processing and distorting what [one] hears" (p. 271). "Self-discovery is the driving, guiding force for a healthy career", adds Buckingham (p. 211). And, as Badaracco puts it, leaders "are responding to powerful, deep-rooted forces that are cultural, psychological, emotional, practical, and perhaps even biological" (p. 50 ).

\section{The Hero-Leader is on a Mission [MIS] and is Creative,} Unorthodox, Divergent [DIV]

Hero-leaders are servants, obedient, undertaking a mission [MIS], and at the same time outsiders, troublemakers, unorthodox rebels, bringing change, novelty and divergence [DIV].

$[M I S]$ The businessmen who earn the admiration of Barnard are those who are "effective in conduct", who "adhere to their codes rigidly in the face of great difficulties", as opposed to those who "have a 'higher' morality" but "do not adhere to their codes when it would apparently not be difficult to do so" (1938, p. 267). Leavitt (1958) underlines the function of authority in putting into action a line of performance and directing oneself towards goals in a coordinated manner. Managers assume responsibility for "setting the frame" (Heifetz, pp. 11-66). They 
produce "credos and mission statements" (Badaracco, p. 27). They concentrate on what are "pegged as the highest priorities" (Ancona and Bresman 2007, p. 98). The point for managers is "to focus people toward performance" (Buckingham, p. 112).

$[D I V]$ During the 1950s, Leavitt described the function of company directors as the establishment of a framework that allows them to immediately concentrate on the theme of change, that is to say what is added by departure from the rule as opposed to what exists. Nor, he insists, is the key to change in the hands only of managers but belongs equally well to employees who act, decide. Motivation comes with seizing the initiative, with a "capacity to exercise a relatively high degree of imagination, ingenuity, and creativity" (McGregor 1960, p. 66). March (1991) outlines the accepted or unforeseen deviance allowed within firms. Heifetz underlines the "creative deviance on the frontline" that leaders experiment with (pp. 183-206). From the title of his book, Buckingham enjoins leaders to "First, break all the rules". X-Teams should work "outside their boundaries" (Ancona, p. 6). Managers should think "creatively and imaginatively about their organization's role in society" (Badaracco 1997, p. 127). They look for an "imaginative recasting of problems and situations" (Badaracco 2002, p. 165). As for the main consultants and researchers working on managerial thought and practices, many since the 1930s can be labelled "heretics" and "radical thinkers" (Kleiner 1996), always "testing theory in action" (Marrow 1969, pp. 153-159). The question of changing behaviour in the sphere of innovation was illustrated in the 1950s by a parallel drawn with Alcoholics Anonymous (Leavitt 1958) and, in the 1990s, by the example of cardiac patients (Heifetz 1994) but the basic reasoning and method are the same: if it is managers who open up the route toward the adaptations required for the survival of the organization, the decision for change belongs to one and all (just as it is the responsibility of the alcoholic or cardiac patient to modify his or her life-style). The call to step outside the boundaries set by one's group is constant: "concentration without, external perspective, attention on clients" (Waterman, p. 315) is applicable to $\mathrm{X}$-Teams who are required to "step outside the limits of the team and attain high levels of outside activity" (Ancona, pp. 6, 63-88). From this perspective, the years 1990-2000 show no historical break with earlier works.

\section{The Hero-Leader is a Negotiator [NEG] and Shows Some Kind of Superpower [SPW]}

The Hero-Leader is a negotiator open to win-win games [NEG], and, at the same time, a warrior for whom some kind of superpower in the midst of battle is a key to success [SPW].
[NEG] According to Lax and Sebenius in their book The manager as negotiator, 1986, negotiation is central to the everyday life of all managers. Since the passage of the National Labor Relations Act in 1935, it has taken the form of a collective bargaining made mandatory by law (French 1975). But negotiation can extend throughout the multiple interactions of everyday work. Mayo (1933) and Barnard (1938) both tackled the difficulties of human "collaboration", "cooperation", and "coordination". Barnard noted that "underlying the formal structure of authority and intraorganization communication are processes of interacting decisions distributed throughout the positions in the lines of communication" (p. 187). Just as Barnard did, emphasizing the notion of "distribution", Malone suggests that management requires a sense of what he calls "distributed leadership" (Malone 2004, pp. 162-167). Management literature is unanimous as regards the fruitfulness of productive in-house conflict: the accent is placed on "an open, confrontationoriented management style in which people go after issues bluntly, straightforwardly" (Peters and Waterman 1982, p. 219); "You need executives (...) who argue and debatesometimes violently-in pursuit of the best answers" (Collins 2001, p. 60). There are conflicts in any project or team work, but, from what Ancona detects in X-teams (teams that succeed) there should be enough "psychological security" so that the fight becomes a "good fight" (p. 93). In a highly creative team, task coordination involves motivating people from outside the team (such as technical people from other teams or top-managers) or even outside the organization (like customers) to contribute. Thus, managers engage in building relationships in which they have to "convince, negotiate, and cajole" (Ancona, p. 185). Negotiation is more or less formal, more or less explicit, more or less contractualist, rational or secret, wrapped to a greater or lesser extent in strategic machinations but always already active in the daily life of companies. It contributes to the creation of "a wise agreement" (Fisher and Ury 1981, p. 14) through methods of "joint problem solving" (Ury 1991, pp. 5-6) and works through "regular dialogue" to sort out problems (Peters and Waterman, p. 223).

$[S P W]$ In 1938, Chester Barnard wrote "The struggle to maintain cooperation among men should as surely destroy some men morally as battle destroys them physically" (p. 278). Although there has been a "transition from sheer physical force to reliance on formal authority" with respect to the means of controlling human behaviour (McGregor, p. 37), the vocabulary of life and death is anything but rare in leadership manuals: for Heifetz, "Leadership is dangerous" (p. 235); it is a matter of "Staying alive" (pp. 233-276). For Ancona, when X-teams have meetings, which is frequently, these resemble "a war room" (p. 104). Whence the heroism of leaders: "The myth of leadership is the myth of the lone warrior: the solitary individual whose 
heroism and brilliance enable him to lead the way" (Heifetz, p. 251). For some authors, violence is mandatory: "it is tough, and people get hurt" (Trump 2009, p. 16); it happens that some team members or managers become "dead men walking" to use Welch's expression (2005, pp. 5,127$)$, a phrase which describes professionals who have lost confidence, do nothing right, are no longer allowed to open their mouths, cannot be looked in the eye anymore and are eventually 'managed' out the door.

\section{The Hero-Leader Matrix in Cinema: Six Case Studies}

The central question remaining is where does the cinema hero stand in this managerial landscape? After watching more than 200 American films, my answer is that the cinema hero stands right in the centre of the Hero-Leader Matrix. For reasons of space, I am not going to list the two hundred films I annotated and I shall restrain myself to six significant examples, sufficient to test the interpretation system I am describing: Five Star Final, 1931; The Maltese Falcon, 1941; Patterns, 1956; Serpico, 1973; Pale Rider, 1985; Avatar, 2009. The choice of these particular films is partially arbitrary in the sense that the two hundred others also conform to the structure I have perceived and could therefore also have provided interesting case studies. The films I have chosen are of different genres (except comedies which, as mentioned above, I did not study). They come from widely differing periods. Some are inspired by workplace situations, some are wildly mythological.

I purposely do not adopt a systematic presentation of the films. For some, I will just analyse the opening; for others, simply give a summarized overview. Occasionally, I will go through a few eloquent scenes. My goal is to show that the Hero-Leader Matrix functions at different levels of the film: the whole thing as well as the micro-scene or sometimes even just an image, from the start right up to the finish, sequenceby-sequence in a fractal manner, which is to say with an invariable structure through all changes of scale.

As I said in the section "Towards a heroic pattern of action", storytelling is not my main interest here as a researcher. Nevertheless, especially for those readers who may not have seen the films, I give a brief glimpse of the stories involved for all, but the focus remains on the mental and practical attitude of the hero towards the actions and interactions with others throughout. The point is to present an idea through the case studies of how the structure identified might be relevant at many levels in many films.

\section{The Excellent Professional: Five Star Final, 1931}

Five Star Final is a five star opening for the Hero-Leader Matrix. Later in the paper, we will see how the story of the
Hero-Leader Matrix unfolds up to Pale Rider (1985) and Avatar (2009), but here, with this pre-code film (Warner Productions), directed by Mervyn Leroy and starring Edward G. Robinson, it seems the whole Matrix is already on the move in Hollywood.

The film takes place in the press milieu. The hero, Joseph Randall, is chief editor of a widely circulated paper, the New York Evening Gazette.

[MIS] Randall is an excellent professional, the best in the place. He fulfils his mission-to increase his paper's circulation, therefore print-run and thus profits-with mastery. The mission is conferred on him by both his own professional sense and by the paper's owner (Bernard Hinchcliffe), the goal being to obtain as wide a "mass circulation" as possible in a neck-and-neck race with other papers. At the start of the film, he is given a new mission by the paper's owner: a report, published in serial form, on a woman (Nancy Voorhees) who, 20 years before, had killed her boss, been acquitted and subsequently remade her life. $\mathrm{He}$ accepts the job against his better wishes, but, once on the case, carries it off with maximum efficacy: "we are going to fry this case over again, and we are going to fry it hot", he says.

[ROL] To be an excellent professional in the tabloid press world means knowing how to stage direct the event, turn it into a show, and that is exactly what Joseph Randall is best at. He puts an ex-priest onto the Voorhees story, inducing him to play the role of a false minister as a pretext for approaching the woman and getting information out of her. He dresses him in a dog's collar: "Get yourself dressed up", he tells him. He wants a photo of the woman in prison but his journalists have only ordinary ones. "Well, then, paint bars on it!" he demands.

[INT] From the start, Randall is living an internal conflict between conscience and mission. Searching out the sensational whatever the cost bothers him. Perhaps there is no room for sentimentalism in the press business, but the hero himself has sentiments. This manifests in his long stares into nothingness. No sooner is he alone than he is invaded by perplexity, and at one point seems devoured by self-disgust. He downs a glass of whisky to soothe the shock of his emotions, later coming up with the theory of the internal pain sedating glass: "God gives us heartache and the devil gives us whisky". Randall does his job, but inside he is finished: "I can't go on with this", he finally declares. $^{3}$

$[S P W]$ At the end of the film, a gutter press editor-inchief with the power to kill is called the "head butcher". That is in a way the moral of Five Star Final. From the start of the film, the hero is presented by the paper's owner,

\footnotetext{
3 "I could not stand it anymore," says the hero of Frizt Lang's Fury, 1936.
} 
Hinchecliffe, as having a "splendid fighting spirit". He does not baulk at using force, quickly evoking his resignation whenever disagreed with. As the story slowly unfolds what is really at stake finally becomes quite clear: it is neither more nor less than a question of the life and death of others. The omnipotence of the press pushes innocent people to suicide, a suicide interpreted as murder. ${ }^{4}$ Finally Randall resigns: "Hinchecliffe will have to get himself a new head butcher".

$[D I V]$ From the start, this hero is a divergent one. $\mathrm{He}$ obeys but keeps his distances through irony. He is the perfect soldier but discreetly allows himself to judge. He is known for his "playful sarcastic tendencies, which is not good for the organization" says the owner. In the end, the hero is practically alone against all other members of the staff (the owner, the journalists and the administration).

$[N E G]$ When you read the dialogues of the film closely, Randall manifests throughout as against his paper's way of going about things. He is a hero of confrontation in permanent conflict with the owner. He confronts him. He expresses his disagreement. He argues, but gives in because he needs his salary. It is, thus, actually an implicit negotiation, a sort of bargaining: he accepts the mission against payment.

The hero finally succeeds, heroically and as a source of dramatic tension, to perfectly fulfil all requirements of the Hero-Leader Matrix: $\mathrm{He}$ has expertly-too expertlycompleted his mission [MIS] as a great and sensationalist stage director, master of communication and manipulator of signs [ROL] in a climate of permanent negotiation [NEG] within which he is obviously different [DIV], his power is seen to be destructive, mortal [SPW], and he pays for it with intense inner suffering [INT].

\section{Ambiguity As Hero: The Maltese Falcon, 1941}

In The Maltese Falcon, there is a whole anthology of negotiation scenes [NEG], mostly carried out with a pistol close to hand, a corpse on the carpet and betrayals punctuating the process [SPW].

The hero, Sam Spade, a detective played by Bogart, carries out a series of particularly difficult confrontations with the head of a small criminal gang. What is at stake is the statuette of a falcon whose value is known to the crook, but only the hero knows where it actually is. They thus have to negotiate so that both can benefit. If we ignore the content of what's being discussed-the famous falcon which turns out to be a fake anyway-the negotiations in

\footnotetext{
${ }^{4}$ As we shall see later in the paper, Patterns, 1956, also has a death scene in the midst of the professional world, a heart attack that is interpreted as a murder ("What happened?" asks the hero's wife, to which he answers, "Nothing... except a murder").
}

The Maltese Falcon are just like any other business negotiation.

At one point, there is a most sophisticated representation of the tensions of modern life, a scene which, in the compass of a few seconds, maximizes all features of the Hero-Leader Matrix. In a luxury hotel suite, the hero, Sam Spade, is carrying out a difficult negotiation with the Fat Man, head of the small criminal gang [NEG]. Negotiation stalls because both protagonists remain firm in their positions [MIS]. Things speed up. In very quick order, less than a minute of the film's total running time, three radically different, even paradoxical models of action, albeit deployed by the same person, are telescoped:

$[S P W]$ The hero tries an all-out approach. He gets mad, throws his cigarette on the ground, gets up, yells and smashes a glass. The power struggle mounts to extremes. Spade threatens to kill the Fat Man's gunslinger, hurls down an ultimatum and storms out, slamming the door.

[ROL] Once out in the hotel corridor having slammed the door, Spade, alone, is filmed in close-up. He walks down the corridor before him, the music a dramatic reminder of the violence of the preceding scene. But, like an actor coming off stage, Bogart relaxes, his approach becomes supple again, he quietly puts his hat on, the music softens, suddenly light. Bogart walks on and his face, now visible to the spectator, is wearing a huge grin. He was playing a game. The hero was pretending, bluffing, simulating anger and violence, but it was just an act, a good performance to trick the other. The hero played a scene, and the public has been taken in.

[INT] But, still in the same sequence, grinning at the great number he has just played on them, at the elevator, Bogart pushes on the button and notices that his hand is shaking uncontrollably. Still grinning, he watches the hand that is out of his control.

Let us pause a moment before this image of a man who smiles in the face of his own trembling. The hero's body is twofold: he is someone with distance as regards his role, an accomplished actor [ROL], and who, thanks to his fine trick, can come away from the negotiation without any real, physical fight [NEG], but at the same time, he is someone who is uncontrollably pushed, discomforted and ravaged by his real emotions, a wild man who trembles at his own violence [INT]. At the elevator, the man who smiles, who play-acts, watches the man who is carried away by his emotions.

Does not this scene from The Maltese Falcon show exactly the situation of negotiators in business or on the international scale? (i) They know they have to enter into a power struggle to defend their positions, points of view, expertise in certain fields or their projects. It is the strategic level, the battle between conflicting interests. (ii) They also know perfectly well that it is a game albeit related to the 
actual lives of the organizations, collectives, or nations they represent, intensified by the plurality of values of modern life, and that there is a part of it that is just playacting, rituals of interaction and role playing within the group dynamic. (iii) Yet, despite such knowledge of role playing and mask-wearing in human interactions, they pay for it directly in emotions, fear, uncertainty, dilemmas, stress and suffering. ${ }^{5}$

\section{The Hero of Confrontation: Patterns, 1956}

In Patterns, Walter Ramsey, president of Ramsey \& Co, a large, New York based company of industrial management, takes on brilliant young engineer Fred Staples to slowly take over the place of Bill Briggs, second in command and one of the oldest company directors. Throughout the film, Ramsey never stops renouncing Briggs in public, stealing his work by claiming it was done by Staples, denigrating and humiliating him with the intention of creating such an untenable position that he will be forced to resign. Briggs finally dies under the pressure of a heart attack.

The main character in the film, and the one who slowly becomes the hero, is the young engineer Fred Staples. Here, I am only analysing the final few minutes of the film following the death of Bill Briggs. My point is that Staples only really becomes the hero in the sense of the HeroLeader Matrix at the very end when, having come to deeply respect Briggs' professionalism, he is faced with his death. The final sequence sees him rise in strength and swiftly manifest all facets of the Hero-Leader Matrix which become concentrated in the hero-to-be at last.

Life at Ramsey \& Co suddenly seems pretty precarious. To survive the battle calls for particular strengths [SPW], Fred Staples' reaction to Briggs' death is final: he calls it murder and this places the aggressor (Ramsey) in a position of omnipotence with the power of life and death over his partners [SPW]. Staples thus decides to resign, to break with this world that disgusts him. He wants to leave New York [DIV]. He goes to Ramsey's office forthwith to tell him. He is completely distraught and this is visible in his expression, his walk, his mounting violence, breath and tone of voice [INT]. He feels he has been manipulated, placed from the start in the role of the one who would take Briggs' place, a role he disapproved of but assumed anyway, going as far as to suggest to Briggs at one moment that he resign [ROL]. Until this moment, he has carried out all tasks assigned him by Ramsey, demonstrating his competence, his capacity for work and his perfect integration into the board of Ramsey \& Co. He is perfect for the job [MIS]. But now he is about to make a break.

\footnotetext{
5 For further developments on The Maltese Falcon c.f. Fournout (2014), pp. 95-137.
}

We do not yet have the complete hero in the HeroLeader Matrix sense at this point. We are still missing negotiation, compromise, and the revolver to the head, so to speak. This difficult negotiation [NEG] takes place during Ramsey and Staples' final meeting. The hero becomes a hero by entering into confrontation rather than just leaving and fleeing the economic and world of business capitol. The terms of the agreement (which are signed and sealed) are brutal. Staples finally stays ("You're the only one who is able to function there", says Ramsey), he accepts a job where he will have to surpass himself, be the best of the best (driven "to heights you've never dreamed of", says Ramsey) [MIS]. He assumes the title of vicepresident knowing perfectly well that Ramsey can use him as a scapegoat, as "another vice-president [he] can push around", as a "whipping boy", just as he did with Briggs [ROL]. He begins a fight to the death with president Ramsey, announces his intention of taking his place, makes the threat physically explicit (reserving to himself the right to knock his face in, break his jaw etc., and, if the president treats him like Briggs, kill him) and Ramsey is satisfied, he wants someone "strong enough to take it" [SPW]. Staples will confront the president whenever he can ("I will argue with you, contradict you, fight you in every way I know how") [DIV]. He expresses his feeling-hatred ("You may take me as someone who hates you down to the bare nerves")—and perfectly incarnates morals and conscience in business, but a conscience that is armed, in battle, in practice ("Be a conscience for me, if you want", says Ramsey) [INT]. All this is concluded on a basis of bargaining (Staples will have all expenses paid, his salary and stock-options doubled), and it is finally Ramsay who is right when he says that "All terms are negotiable" [NEG].

To keep all the partially contradictory promises of the Hero-Leader Matrix is not a "done deal" seems to be the conclusion of Patterns. But the stakes are that the hero of confrontation has a chance.

\section{The Disguised Hero, True to Himself: Serpico, 1973}

In Serpico, the eponymous hero played by Al Pacino definitely earns the title of a perfect Hero-Leader. The whole plot seems dedicated to building up a hero who, despite extreme difficulties, is never defeated. He manages to recruit help: just as Don Quixote convinces Sancho Panza to follow him, he, too, enrols people in his quest. Every scene supplies the Hero-Leader Matrix with new developments.

Let us just examine the opening sequences of Serpico. The six structural facets of the Hero-Leader Matrix appear almost immediately at the very start of the film:

[INT] The hero deeply interiorizing During the first sequence Serpico, covered in blood, is close to dying, 
lying in the back seat of a police car racing towards hospital. We hear the siren blaring and the monotonous noise of the windshield wipers (it is raining outside). The noise is haunting, as if Serpico's final remaining sense is his hearing and the spectator is inside his ears, hearing from his perspective. At the hospital, the doctor looks into his eye which we thus discover close-up. The eye moves from right to left: a sign of remaining inner life. Serpico is thinking of his past, and this is the starting point of a flash back. We are thrown into his memories of the ceremony in which he was sworn in as a police officer in 1960 . He is listening to a speech with intense, almost mystical, attention.

[ROL] The hero in a role Serpico in the police car being rushed to the hospital is dressed like a bum. He has a long beard a little like a South American guerrillero or character from a Dostoyevsky novel. A few seconds later, during the ceremony (start of the flash-back), he is beardless and in uniform with short cropped hair. There are clearly two Serpicos, two distinct roles, two costumes. [MIS] The hero on a mission The speech during the ceremony is a reminder to the newly sworn in officers of their principal duties as policemen: to fight crime, obey the law and defend the dignity of all individuals. Serpico gives these goals full credence. The "heroic" is not arbitrary: it demands a link with a societal or cultural standard, with a code of conduct, commonly recognized, and measurable benchmark. In Serpico, this very soon becomes explicit.

[DIV] The unorthodox hero making divergent moves As Serpico is taken into the hospital, we see police officers talking to each other. Although we do not yet know why, we learn that he might have been shot in the face by another policeman. He is apparently threatened by his own professional community and in danger from his colleagues. The hero has obviously taken some kind of divergent initiative.

[NEG] The hero as a negotiator Among the police officer's skills praised during the ceremony, we hear of "tolerance", "courtesy" and "patience", skills Serpico will manifest in the exercise of his duty and which facilitate a negotiation approach to problems at hand.

[SPW] The hero with a special strength, struggling for his life, displaying a sort of omnipotence and superpowers Shot at the face, Serpico struggles to stay awake. His life hangs by a thread. He is close to dying but resists. His will to live is unaltered.

Within $3 \mathrm{~min}$, the six criteria have fashioned the very definition of what Serpico is and will remain throughout the whole film. A hero with a vital force, taking on risks [SPW], diverging from the normal course of police department routine [DIV], negotiating wherever possible
[NEG] but inflexible when it comes to his duty and mission [MIS], fully aware of his own life, conscience, moral standards, passion and values for which he is prepared to fight [INT] and assuming different roles and different guises within society [ROL].

The Hero on the Side of the Little Man: Pale rider, 1985

The Internet Movie Data Base sums up Pale Rider as follows: "A mysterious preacher protects a village of humble prospectors against an ever more voracious mining company trying to encroach on their territory". ${ }^{6}$

$[R O L]$ The hero (played by Clint Eastwood) is a twosided character-a preacher and a killer. He has two emblematic accessories-a preacher's dog-collar and a sharp-shooter's pistol. When he takes the revolver from the case where it is locked up, he puts the starched collar back in its place like an actor changing costume during a performance.

[INT] By a multitude of signs, the hero shows that he is one with his own interiority. He takes the time to look at the world. His reserve in showing his feelings is still a sign that he has feelings, a rhetorical sign of a profound awareness that helps him distance from events. He is a thinking witness, carried by a faith married to silence, to an economy of words and to detachment. Eastwood, each time he appears, in each shot, reminds us that, though he may be in action, he is also steeped in thought, emotion, judgment, and sensation.

$[M I S]$ The hero clearly takes charge of a mission. He puts himself at the head of a small resistance group. He organizes them and gives them hope and assistance. He has laws and rights respected. Behind the scenes he defends values-family, dignity, remembrance of the dead, protection of the weak against the power of money as a corrupting agent.

$[D I V]$ The hero keeps his distance from others. He is apart. There is "something strange about his eyes" as one of the characters remarks. He is a loner, a trouble maker. "Who are you really?" asks one of the prospectors' wives. There is a somewhat dandyish touch to the way he dresses: he wears a mauve coat which is not exactly standard issue for the cowboys of the region. He has a discreet charm which is not lost on either women or men.

[NEG] $\mathrm{He}$ is a negotiator and opens the way to discussion. He knows how to bargain. He gets the major owner, the prospection tycoon, to pay $\$ 1000$ rather than $\$ 100$ as damages to the smalltime prospectors, unarmed and poor. He works toward reconciliation.

\footnotetext{
${ }^{6}$ A Clint Eastwood film starring Clint Eastwood. It was nominated for a Palme d'Or at the Cannes Festival and received a prize for best scenario from the Association of Western Writers of America.
} 
$[S P W]$ The devil and death follow him. He brings violence. He is a sort of horseman of the Apocalypse on a pale grey horse. He scares people. He never hits first but his defensive action is always more telling than the initial offence.

Like many others, Clint Eastwood's films are distinguished by a doctrine of violence whose equivalent in the managerial world would be, at first sight, the principle "Think big and kick ass" (Trump 2009). That said, however, even in violent films, the movie hero is more complex. The character in Eastwood's film who applies the "Think big and kick ass" to the letter is the rich and shady prospector. As for the hero, he introduces a resistance to power. He is a hero precisely because he is not just the messenger of brute force. Sure enough, he does pay homage to the realism of the trigger [SPW], reminding us that the good intentions of the poor prospectors are not much help in the face of terror. But he carries in him a far richer plan of action that covers the six requirements of the Hero-Leader Matrix. He pledges his interiority (morally whole, emotional, reflecting, and, to top it all, a preacher) [INT]. He unites the group of prospectors by example and through the hope he distills [MIS]. If he does use force, he knows how to dose it, he is in a sort of well-directed ascent: he strikes those who strike, shoots the potential rapist in the hand, kills the marshals hired by the big prospector, empties his barrel into their chief. He is in a sort of "give-andtake" negotiation [NEG]. The subtlety of adjustment in such strategies (that Axelrod 1984, would call strategies of reciprocity) implies an intelligence of situations. The hero is gratuitously gifted not only with a beauty of gesture (the service of God and transcendental justice), but also with a capacity for analysis, calculation, reflection and decision based on awareness [INT]. He reconciles the realms of action (extreme) and contemplation (no less extreme). $\mathrm{He}$ is both preacher and knight [ROL]. This paradoxical synthesis renders him utterly inaccessible to ordinary mortals and the other characters in the film thus never really know who he really is [DIV]. In short, he is a leader in the simplest of senses: he helps a small community structure itself, shows them the example of work shared where each one strives for the benefit of the whole [MIS]. Since he is a "professional" who excels in the handling of technique, the outcome for his opponents is inevitably fatal [SPW].

\section{Another King of the World: Avatar, 2009}

Avatar $^{7}$ is like the decisive outcome of the long cinematographic tradition I describe in this article. It pushes the Hero-Leader Matrix logic to its limits as if the leading idea

\footnotetext{
${ }^{7}$ Film by James Cameron with Sam Worthington.
}

of both director and producer is to give each of the six main features a never before seen intensity yet still maintain a well-anchored structure.

The hero assumes a role [ROL]: by simply reading the title, Avatar, the spectator expects to be thrown into a story of metamorphosis (an "avatar", says the Webster's Dictionary, is "an incarnation or metamorphosis of a deity"). From the very start, it is a radical version of assuming a role. The actor's mask becomes a complete physical body of strange appearance, an avatar. Actor of extremes, the hero plays an other-a thorough-goingly extraterrestrial blue elf.

The hero interiorizes [INT]: the sensations, hopes and feelings of the hero are increased tenfold by his physical handicap. His need to love and to act is reinforced by his furious need to escape the strict limits of his wheelchair. His interiority stretches to the point where he enters into direct communication with the sensitive soul of the planet itself in a sort of osmosis of personal and cosmic sensitivities.

The hero is on a mission [MIS]: the mission becomes enormous. The hero is to save an entire planet and all its people, an eschatological ambition. The possible extermination of a world (our own?) is on the horizon.

The hero is divergent [DIV]: the hero sets himself apart from both opposing camps, the natives of the planet as well as the human colonists. He is rejected by them all including his most loving companion. He is the perfect outsider. Moreover, the ethics he espouses are a sort of negative image of the dominant ethics of the modern world: he champions a holistic, anti-productionist, contemplative conception respectful of other cultures.

The hero negotiates [NEG]: he favours the paths of negotiation. Though a professional soldier, he is a negotiator at heart. He avoids violent confrontation by all means possible. He tries till the very end to bring about compromise between the two camps involved. The aggression does not come from him.

The hero is all-powerful [SPW]: he is excellent in all details of combat, a peak performer. He manifests supernormal qualities, mastering natural powers by taming a mythical beast-something that only happens once in several generations and marks the one who does so as a king — king of the planet.

The hero of James Cameron's previous blockbuster, Titanic, 1997, had already declared I am the king of the world. There is a sort of leitmotiv here, but one that goes beyond the simple affirmation of omnipotence [SPW] and a mission to accomplish [MIS] in that it always has to do with setting oneself apart from the common man and bringing about innovation through breaking away [DIV], negotiating [NEG], showing oneself to be impassioned and 
authentic, true to one's feelings [INT] and casting oneself body and soul into one's assumed and precarious roles [ROL].

\section{Conclusion and Discussion: A Modern Hero- Leader Figure on a Civilizational Scale}

In this paper, I have used the same set of six features to describe the position of the hero in films and in organizations. According to my research, the same model is transmitted by both Hollywood and management texts. The figure of the hero promoted by management literature and the American film industry is the same at a structural level, and it has been built up over a long period of time, since the first talking movies in the 1930s, in fact, when, for the first time in the social world, management issues also began to take the human dimension of industrial organization into account (Mayo 1933; Barnard 1938; Maier 1946; Leavitt 1958; McGregor 1960). My aim has been to explore this hypothesis, and I have provided elements that could describe the profile of this one dominant type of hero.

Out of the examination of texts on management and of American cinema arises a picture of the complexity of modern life and the challenges needed to meet it that weigh particularly on those whose task it is to organize collaboration between people (managers). The strategic means may be handled with great competence in a form of excellence [MIS], while at the same time demanding consummate mastery of acting, stage direction, pretense and ruse-certain modern management treatises going so far as to take Machiavelli as model [ROL]. At the same time, this game implies enthusiasm; it entails an intimate upheaval not incompatible with an involvement of the self and with real and powerful existential engagements shaking body and soul to the point of possible affective ravages and suffering [INT]. American film (grand cinema) and management texts assure us that the hero-leader is, of course, play-acting [ROL] and that a well-played part can help in a negotiation [NEG], but they also tell us that the actor will pay for this in real emotions [INT]. It is a façade, but not just pure façade. It also entails real, internal involvement, emotional upheaval, genuine pleasure and real fear. Films warn us of this in a visual way, a trembling hand, for example (The Maltese Falcon), and manuals on management through practical descriptions in words and concepts. In order to be credible, to have weight in the action and negotiation, the acting must be rooted in real emotions that fill the actor (the hero or leader) from within in order to accomplish the mission [MIS]. The winner (almost always the hero) is the one who, in the long run and through many trials, sets himself apart by his initiative and his creative actions [DIV], risking stress, loss of self, anxiety, intoxication, overload, exhaustion, insomnia, obsession, heart-problems, and, in short, premature death [SPW].

The heroic structure thus revealed obeys a fractal law: (i) it goes for the profile of the hero-leader, expressing itself throughout an entire film or management manual taken as a whole; (ii) it applies from the first few minutes, the opening sequences of a film, the opening chapters of books; (iii) with varying intensity, often crescendo, it exists in most of the scenes and developments that follow; and finally (iv), the fractal law also goes beyond the strict framework of film or manual because its structure is also found more widely in the social world, in a collection of films and texts over a long period of time concerning life, presentations of management and heroic lives.

A certain difficulty in fulfilling all conditions of the HeroLeader Matrix because of its internal tensions also makes itself manifest. The modern hero-leader has to follow a series of prescriptions that are not easily reconcilable. It is not just that the mission is difficult or that situations are tense, it is that heroes and leaders have to accomplish their mission and face tensions while conforming to a behavioural mould (the Hero-Leader Matrix) which itself exacerbates the tensions, contradictions and complexities. Anyone in the modern world who seeks to approach the figure of the hero, leader or hero-leader must simultaneously meet the following six requirements: involve themselves entirely [INT] in the game of appearance [ROL]; surpass themselves in the accomplishment of their mission [MIS] by smashing its framework [DIV]; and negotiate [NEG] with a revolver to their head and another in their hand [SPW].

Heroism is a heroism of paradox, a praxis of oxymora. The hero-leader goes through situations that stir dilemmas in him, dilemmas that are dictated by the exterior (with every manner of personal story imaginable) and dilemmas brought about by his own system of action and interaction (the Hero-Leader Matrix). His ability to function in the environment depends on his ability to handle these dilemmas both internally and externally.

Certain ethical implications of the findings can be further underlined.

- One is that every new manual on management tends mainly to stress what is new in terms of behavioural standards in the workplace. That, of course, is a fully justified point of view. But, on the other hand, what also seems important is to take into account the great stability and robustness of the chief ethical and esthetical features over long periods of time through which the modern hero-leader acquires the flavour of a mythological figure.

- If an evolution can be pointed out, it is more in terms of intensity than of quality. With time, it seems the 
features of the Hero-Leader Matrix are pushed forward, intensified, exaggerated, and become more and more spectacular. Both the film Avatar and the story of $X$ teams in the managerial scope deeply value existential extremism in the way life must be led in order to succeed in the world. Not only does this shed light on why it is not easy to be a manager today, but it may also help understand how burnout situations can arise among managers and top managers who-up to the point where they break-do their job quite successfully.

- Such research may bring new understanding of the use of popular film in business and academic fields. Not only do films provide great illustrations of concepts and methods but they also convey a more profound representation of the major type of modern hero shared by organizations and the dominant myth producers of our societies (Hollywood). Unlike Greek heroes, for example, however, the figure of the modern hero-leader does not have a single name. It is more of a collective embodiment than an identified character such as Prometheus or Ulysses. Its ethical appeal is facilitated by its many possible identities.

- One final implication is methodological. When treating ethics in the organizational sector, one should always bear in mind the general mythology, fictional and practical, within which it is embedded. If Weber was right to speak of an "immense cosmos in which the individual is born" as regards the ethical maxims circulating within societies, then part of the so-called "cosmos" should undoubtedly include the imaginative and fictional works that the popular movie industry, TV series and computer games, present as models and ideal-types to our spectatorial minds and bodies.

Just as the world of knighthood in the Middle Ages had its treatises on ethics and practice (its practical literature), its novels (its fictional works) and its rituals, all uniting in a form of social conduct, one might equally assume that management texts (practical literature) and management training (rituals) and the movies made by Hollywood (fictional works) all also tend toward the construction of a single hero-leader figure on a civilizational scale, the one embodied by the Hero-Leader Matrix.

This study of a double empirical terrain-film and management texts-opens on at least two research questions not yet treated:

(1) If there is tension between the requirements of the Hero-Leader Matrix, if there is a paradox or a contradiction, is one to conclude that the paradox and tension remain open, or does resolution come about on a higher level of synthesis not yet revealed or even, perhaps, recognized in the treatises and films? Where does the synthesis come into being, and, if there is not one, what is this telling us about modernity itself?

(2) The ethical lines of conduct nurtured by the HeroLeader Matrix do not just spring from the cinematographic and managerial ground as though from some primal ocean. How do they fit into the political and intellectual history, that of the West in general and of the USA in particular?

These suspended questions call for complementary research in both American and Western thought and history. It would be no small advance to recognize how influential managerial literature and popular cinema have been in the creation of a major heroic figure located in the very heart of what is philosophically and historically at stake in Western Civilization in the long run.

Open Access This article is distributed under the terms of the Creative Commons Attribution 4.0 International License (http://crea tivecommons.org/licenses/by/4.0/), which permits unrestricted use, distribution, and reproduction in any medium, provided you give appropriate credit to the original author(s) and the source, provide a link to the Creative Commons license, and indicate if changes were made.

\section{References}

\section{Management Bibliography}

Allison, G., \& Zelikow, P. (1999). Essence of decision: Explaining the Cuban Missile Crisis. New York: Addison-Wesley Educational Publishers.

Ancona, D., \& Bresman, H. (2007). X-teams: How to build teams that lead, innovate, and succeed. Boston: Harvard Business School Press.

Axelrod, R. (1984). The evolution of cooperation. New York: Basic Books.

Badaracco, J. L. (1997). Defining moments: When managers must choose between right and right. Boston: Harvard Business School Press.

Badaracco, J. L. (2002). Leading quietly: An unorthodox guide to doing the right thing. Boston: Harvard Business School press.

Barnard, C. I. (1938, 1968). The functions of the executive. Cambridge: Harvard University Press.

Bennis, W. G., \& Thomas, R. J. (2002). Geeks and geezers: How era, values, and defining moments shape leaders. Boston: Harvard Business School Press.

Besser, T. L. (1996). Team Toyota: Transplanting the Toyota culture to the Camry Plant in Kentucky. New York: State University of New York Press.

Blake, R., \& Mouton, J. (1964). The managerial grid. Houston, TX: Gulf.

Boltanski, L., \& Chiapello, E. (2005). The new spirit of capitalism. London, New York: Verso (translated from the French (1999)). Le nouvel esprit du capitalisme, Paris: Gallimard.

Bolton, R. (1979). People skills. New York: Simon \& Schuster.

Bolton, R., \& Bolton, D. G. (1996). People styles at work. New York: Amacom. 
Buckingham, M., \& Coffman, C. (1999, 2001). First break all the rules. New York: Simon \& Shuster.

Carnegie, D. (1936, 2004). How to win friends and influence people. London: Vermilion.

Carnegie, D. (1926, 1956). How to develop self-confidence and influence people by public speaking. New York: Pocket Books.

Collins, J. (2001). Good to great. London: Random House.

Crozier, M. (1989, 1994). L'entreprise à l'écoute. Apprendre le management post-industriel. Paris: Seuil.

Deming, W. E. (1982, 2000). Out of the crisis. Cambridge, MA: The MIT Press.

Drucker, P. F. (1967, 1970). The effective executive. London: Pan Books.

Fisher, R., \& Ury, W. (1981, 1991). Getting to yes, negotiating agreement without giving in. New York: Penguin Books.

French, C. E. (1975). Management and industrial relations 19191970, privately published.

Galbraith, J. R. (1977). Organization design. Reading: AddisonWesley.

Goleman, D., Boyatzis, R., \& Mckee, A. (2002). Primal leadership. Boston: Harvard Business School Press

Gross, D. (1996). Greatest business stories of all time. New York: Wiley.

Heifetz, R. A. (1994). Leadership without easy answers. Cambridge, MA: The Belknap Press of Harvard University Press.

Herzberg, F., Mausner, B., \& Bloch Snyderman, B. (1959, 2010). The motivation to work. Transaction Publishers: New Brunswick.

Katz, D., \& Kahn, R. L. (1966, 1978). The social psychology of organizations. New York: Wiley.

Kleiner, A. (1996, 2008). The age of heretics: A history of the radical thinkers who reinvented corporate management. San Francisco: Jossey-Bass.

Kotter, J. P., \& Cohen, D. S. (2002). The heart of change: Real-life stories of how people change their organizations. Boston: Harvard Business Review Press.

Lazear, E. P. (1998). Personnel economics for managers. Hoboken: Wiley.

Lax, D. A., \& Sebenius, J. K. (1986, 1995). The manager as negotiator. New York: The Free Press.

Leavitt, H. J. (1958). Managerial psychology. New York: University of Chicago Press.

Lempereur, A., Colson, A., \& Pekar, M. (Eds.). (2010). The first move: A negotiator's companion. Chichester: Wiley.

Lewin, K. (1935). A dynamic theory of personality. New York: McGraw-Hill Book Company.

McGregor, D. (1960, 2006). annotated edition by Cutcher-Gershenfeld, J. The human side of entreprise. New York: McGraw-Hill.

Maier, N. (1946). Psychology in industry. Boston, MA: Houghton Mifflin Company.

Malone, T. W. (2004). The future of work. Boston: Harvard Business School Press.

March, J. G. (1991). Exploration and exploitation in organizational learning. Organization Science, 2, 71-87.

March, J. G. (1994). A primer on decision making: How decisions happen. New York: The Free Press, Simon \& Schuster Inc.

March, J. G., \& Weil, T. (2003). Le leadership dans les organisations. Paris: Les Presses de l'École des Mines.

March, J. (2003). Passion and discipline. documentary film, private copy.

Marrow, A. J. (1969). The practical theorist: The life and work of Kurt Lewin. New York: Basic Books.

Maslow, A. (1954). Motivation and personality. New York: Harper \& Row.

Mayo, E. (1933, 1992). The human problems of an industrial civilization. New York: The MacMillan Company.

Mintzberg, H. (1973). The nature of managerial work. New York: Harper \& Row.
Mintzberg, H. (2004). “Enough leadership”, Harvard business review. Boston, MA: Harvard Business School Publishing Corporation.

Morgan, G. (1986). Images of organization. Newbury Park: Sage Publications.

Peters, T., \& Waterman, R. (1982, 1984). In search of excellence: Lessons from America's best run companies. New York: Warner Books.

Robbins, S. P., \& Coulter, M. (1996, 2007). Management. Upper Saddle River: Pearson Education.

Scott, B. (1981, 1986). The skills of negotiating. Aldershot: Wildwood House.

Senge, P., Roberts, C., ROSS, R., SMITH, B., \& KLEINER, A. (1994). The fifth discipline fieldbook. London: Nicholas Brealey Publishing.

Senge, P., \& Käufer, K. (2001). Communities of leaders or no leadership at all. New York: Prentice Hall. Retrieved July 11, 2012, from http://www.s3.amazonaws.com.

Trompenaars, F. (1993). Riding the waves of culture: Understanding cultural diversity in business. London: The Economist Books.

Trump, D. J. (2009). Think big: Make it happen in business and life. New York/London: Harper.

Ury, W. (1991). Getting past no: Negotiating your way from confrontation to cooperation. New York: Bantam Books.

Welch, J. (2005, 2007). Winning. London: Harper.

Womack, J. P., \& Jones, D. T. (1996, 2003). Lean thinking: Banish waste and create wealth in your corporation. London: Simon \& Schuster.

\section{General Bibliography}

Ames, C. (2009). PR goes to the movies: The image of public relations improves from 1996 to 2008. Public Relations Review, 36, 164-170.

Beard, V. (1994). Popular culture and professional identity: Accountants in the movies. Accounting, Organizations and Society, 19(3), 303-318.

Bell, E. (2008). Reading management and organization in film. New York: Palgrave Macmillan.

Campbell, J. (1949, 1968). The hero with a thousand faces (2nd ed). Princeton, NJ: Princeton University Press.

Cavell, S. (1981). Pursuits of happiness: The hollywood comedy of remarriage. Cambridge, MA: Harvard University Press.

Champoux, J. (2001). Using film to visualize principles and practices. Cincinnati: South-Western College Publishing.

Denning, S. (2005). The leader's guide to story telling. San Francisco: Jossey Bass.

Dewey, J. (1934, 2005). Art as experience. New York: Penguin Group.

Dimnik, T., \& Felton, S. (2006). Accountant stereotypes in movies distributed in North America in the twentieth century. Accounting, Organizations and Society, 31(2), 129-155.

Feldman, S. (1992). At the movies: Business gets a bad rap. Management Review, 81, 49-54.

Felton, S., Dimnik, T., \& Bay, D. (2008). Perceptions of accountants' ethics: Evidence from their portrayal in cinema. Journal of Business Ethics, 83, 217-232.

Fournout, O. (2012). La fabrique du héros hollywoodien. L'acteur et 1'intériorité. Communication \& Langages, n¹72, Juin 2012, 137-156.

Fournout, O. (2014). Héros. Action, innovation, interaction dans les organisations et au cinéma. Paris: Presses des Mines.

Goffman, E. (1959). The presentation of self in everyday life. New York: Doubleday Anchor Books. 
Guigueno, V. (1998). Cinéma et société industrielle: le travail à la chaîne à l'épreuve du burlesque, in de BAECQUE, Antoine, and DELAGE, Christian (dir.) De l'histoire au cinéma. Paris, Ed. Complexe.

Hassard, J., \& Holliday, R. (1998). Organization representation: Work and organizations in popular culture. London: Sage Publications.

Hinton, D. B. (1994). Celluloid ivy: Higher education in the movies 1960-1990. Metuchen, NJ: Scarecrow Press.

Illouz, E. (2007). Cold intimacies: The making of emotional capitalism. Cambridge: Polity Press.

James, W. (1906, 1995). Pragmatism. New York: Dover Publications. Jarvie, I. C. (1970). Movies and society. New York: Basic Books, Inc.

Jeantet, A., \& Savignac, E. (2012). Représentations du monde professionnel et du rapport subjectif au travail dans les films de fiction français contemporains. In A. Jeantet (dir.), "Cinéma et travail", Travailler, 27.

Johnson, B. (1995). Now showing: Hollywood's best and worst bosses. Sales and Marketing Management, 147(8), 44-45.

Kracauer, S. (1947, 2004). From Caligari to Hitler: A psychological history of the German film. Princeton: Princeton University Press.

Lamendour, E. (2012). Les managers à l'écran. Enquête sur une image déconcertante. Rennes: Presses Universitaires de Rennes.

Langford, D. A., \& Robson, P. (2003). The representation of the professions in the cinema: The case of construction engineers and lawyers. Construction management and Economics, 21, 799-807.

Lee, M. (2001). The image of the government flack: Movie depictions of public relations in public administration. Public Relations Review, 27, 297-315.

Lee, M. (2004). What does hollywood think nonprofit CEOs do all day? screen depictions of NGO management. Public Organization Review: A Global Journal, 4, 157-176.
Liebes, T., \& Katz, E. (1990). The export of meaning: Cross-cultural readings of Dallas. New York, Oxford: Oxford University Press.

Lithgow, J., Corey, M., \& Taylor, E. (2001). Celluloid CapitalismEntrepreneurs in Action. The Journal of Economic History, 61(02): 524-525. Cambridge: Cambridge University Press.

Locke, J. (1689, 1964). An essay concerning human understanding. New York: The New American Library.

Marion, J.-L. (1997, 2002). Being given: Toward a phenomenology of givenness. Stanford, CA: Stanford University Press.

Miller, K. S. (1999). Public relations in film and fiction: 1930 to 1995. Journal of Public Relations Research, 11(1), 3-28.

Gareth, M. O. R. G. A. N. (1997). Images of organization. Thousand Oaks, CA: Sage Publications.

Paietta, A., \& Kauppila, J. (1999). Health professionals on screen. Lanham, MD: Scarecrow Press.

Propp, V. (1928, 1968). Morphology of the folk tale. Austin: University of Texas Press.

Rombach, B., \& Solli, R. (2006). Constructing leadership: Reflections on film heroes as leaders. Sweden: Santérus Academic Press.

Ross, S. (2001). American workers, American movies: Historiography and methodology. International Labor and Working Class History, 59, 81-105.

Shaw, B. (2004). Hollywood ethics: Developing ethical issues... hollywood style. Journal of Business Ethics, 49, 167-177.

Soter, T. (1996). Looking for Mr. Good Guy. Management Review, $85(8), 32-36$.

Strasberg, L. (1988). A dream of passion: The development of the method. New York: Plume.

van Es, R. (2003). Inside and outside The Insider: a film workshop in practical ethics. Journal of Business Ethics, 48, 89-97.

Weber, M. (1904, 2003). The protestant ethic and the spirit of capitalism. Chemsford, MA: Courier Dover Publications. 